\title{
A Comparative Study of Female Transgressors in Tess Onwueme's The Broken Calabash and the Reign of Wazobia: A Feminist Critical Discourse Analytical Perspective
}

\author{
ARAGBUWA, Adetutu (Ph.D.) \\ Department of English \& Literary Studies, Ekiti State University, Ado-Ekiti, Nigeria
}

*Corresponding Author: ARAGBUWA, Adetutu, Department of English \& Literary Studies, Ekiti State University, Ado-Ekiti, Nigeria

\begin{abstract}
Several literary critics have examined women's resistance against male oppression in many Nigerian-authored plays. However, a feminist critical discourse analysis of female transgressors' dramatic deviance from expected gender relations in Nigerian drama remains an under-researched aspect of the literature. This study, therefore, seeks to perform a comparative exploration of female transgressors in Tess Onwueme's The Reign of Wazobia and The Broken Calabash via Lazar's (2007) feminist critical discourse analytical framework. From the discourse structures in the plays, findings reveal that female transgressions in the two plays act as counter-ideological moves meant to portray the friability of the prevailing ideological gender order and also to undermine its naturalness and normalcy. The study demonstrates that the success of Wazobia and failure of Ona in The Reign of Wazobia and The Broken Calabash, respectively, are contingent upon women's solidarity. The study, therefore, places in the foreground the significant role of women's solidarity in female transgressors' struggle against male hegemony.
\end{abstract}

Keywords: feminist critical discourse analysis, drama and male dominance

\section{INTRODUCTION}

Although some patriarchal cultural practices have apparently sustained peace and order in the society (Ezenwa-Ohaeto, 2015), most of the practices are believed to be in favour of men, and are therefore, oppressive to women. The marginalisation of women in most cultures has now birthed the reality of the "patriarchal state" that functions solely in the interests of men and sustains the stereotypical gender order that supports the oppression of women (Dahlerup, 1987; Kong \&Chan, 2000; Wilson, 2013). The gender order, transmitted from generation to generation, subtly ensures the conformity of girls/women to the expected cultural/behavioural values and any female who fails to conform to these cultural expectations are often seen as transgressors in the society (Katongo, 2013; Cheru, 2013). In contemporary times, women's quest for freedom from burdensome patriarchal practices has birthed diverse movements locally and internationally. Although the movements operate different ideologies, nevertheless, their united goal is to dethrone/eliminate patriarchy and implement "a cultural rebirth" for the womenfolk (Ezenwa-Ohaeto, 2015, p. 61).

Nigerian male and female playwrights have written much about the plights of the African women. Over time, gender-sensitive critics have vehemently frowned against the negative portrayal of Nigerian women in diverse familial contexts, most especially in male-authored plays like: The Trial of Bother Jero by Wole Soyinka, Ovonramwen Nogbaisi by Ola Rotimi, etc. These male playwrights are criticised for their celebration of the stereotypical negative depiction of Nigerian women in their female dramatic creation.

Female-biased plays of such nature are now being replaced by plays that portray African women's incessant struggle against male dominance within the African experience. Women's quest for liberation from patriarchal cultures has notably become a dominant theme in most-gender based Nigerian plays. Playwrights like Tess Onwueme, Zulu Sofola, Ola Rotimi, Patricia Ogundipe, Stella Oyedepo, Yerima Ahmed, Iyorwuese Hagher and Wale Ogunyemi have engaged with the African women experiences and championed the cause of the female essence in Africa. Their giant literary strides have changed the trend of female dramatic creation in African plays (Nwanya \& Ojemudia, 2014). 
Each of these playwrights has uniquely-defined female dramatic creation. For instance, Stella Oyedepo's The Rebellion of the Bumpy-Chested (2002) is a typical depiction of women radicals who stage a gender-based battle orchestrated to rearrange the traditional social order. In the play, men are pictured as the enemy who must be overthrown while women are the victims who seek to liberate themselves from the oppressive supremacy of men and establish their own superiority (Ezenwanebe, 2008).Stella Oyedepo's female dramatic portrayal is criticised as radical feminism, a "coup against male supremacy and a threat to societal peace" and it consequently acquires a "pejorative undertone" (Ezenwanebe, 2008, p. 187). Opposition against radical feminism has, thus, led to the emergence of Womanism, an African-centred type of feministic ideology propounded to extol gender complementarity, female independence, cooperation in the family and motherhood (Evwierhoma, 2016). Ahmed Yerima, too, is a prolific writer whose plays have demonstrated women's agitation against male oppression as seen in Aetu, a play that decries "girl-child marriage dilemma" and its devastating impacts on not just the girl-bride, but also on her offspring and the society at large (Awoyemi, 2014, p. 7). Notwithstanding his passion towards the plights of Nigerian women in a male-dominated oppressive culture, his portrayal of the images of educated and career-driven female characters in some of his plays like: The Sisters; The Portraits; and The Mirror Cracks, depicts a "gentle satire" of career women in the African context while empathising with the plights of the uneducated village characters (Ezenwanebe, 2008, p. 198).

Furthermore, Nolas-Alausa (2012) appraises two plays of Tess Onwueme, The Reign of Wazobia and The Broken Calabash, in order to mirror African women's struggle against patriarchy and their agitation for women's rights in the African socio-cultural context. The work reveals that there is a covert awareness amongst Nigerian female dramatists that gender equality in the African context appears almost impossible; hence the need to demonstrate through their plays that the inequalities between the two genders are "male-conceived, male-erected and male-executed" (p.3), and the need for women themselves to chart ways for their emancipation from male dominance. The work also reveals that through "bonding", women must striveto "reduce the pain, distress and hurt which patriarchy inflicted on them" and "harness their collective strength to ensure that power acquisition and distribution is not executed to their detriment"(Nolas-Alausa, 2012, pp. 12\& 15). Udengwu (2002, p. 135), however, argues that "the image of the doomed educated woman still persists" in plays written by some female playwrights like Tess Onwueme in Tell it to Women and Zulu Sofola in The Sweet Trap, and even in Stella Oyedepo in The Rebellion of the Bumpy-Chested.

Despite the plethora of studies on women's struggle against male oppressiveness in the Nigerian patriarchal culture, the portrayal of female transgressors in Nigerian plays remains an underresearched aspect of the literature. This study, therefore, engages with Tess Onwueme's The Broken Calabash and The Reign of Wazobiawith a view to explore the female dramatic creativity of the Nigerian author. Specifically, the aim of the work is to perform a comparative feminist critical discourse analysis of the discourse structures of the female transgressors created in the patriarchal domains of the plays; elicit the ideological constructions of their discourse structures; and analyse the discourse implications of their dramatic creation in effecting social transformation. This knowledge is expected to serve as are source tool for the various feminist movements on how to (re)position their struggle for a social reorder.

\section{LiTERARY DiSCOURSE ANALYSIS}

Analysis of literary texts, for decades, has focused on two major traditions: the hermeneutic approach which centers on the text and a contextual approach that "appeals to major cultural formations thought to impose certain requirements on literary production and reception" (Miall, 2002, p. 321). However, Hasan(1985) cited by Dooga (2009, p. 133) reveals that literary criticism remains "a series of personal preferences" without linguistic analysis. This, therefore, leads to the interface between literature and linguistics. However, linguists have mostly applied stylistic and pragmatic concepts to the study of literary texts.

Kies (1992), for instance, performs a linguistic and stylistic analysis of the literary language George Orwell deploys in writing his masterpiece, Nineteen eighty-four. Kies's analysis reveals fourteen syntactic devices used by Orwell in the novel to portray how the thoughts and actions of human agents in a totalitarian state are manipulated, suppressed and rendered passive by the power of the 
state, (the principal). Asiyanbola (2016) also explicates the pragma-linguistic meanings that are significant to the interpretation of two poems: The Casualties by J.P. Clark and Song of Sorrow by Kofi Awoonor. Linguistic elements such as deviation, dominance, syntactic parallelism and repetition are identified in the poems as linguistic, social and pragmatic clues that enhance the literary interpretation of the poems. Likewise, scholarly linguistic studies on Ahmed Yerima's plays (e.g. Odebunmi, 2006; Adeniji \& Osunbade 2014a, 2014b; Acheoah \& Sunday, 2014; Adegoju, 2016) have focused largely on their stylistic and pragmatic features as well as their context-sensitivity to the realities in Nigeria. Despite numerous studies on the linguistic deconstruction of literary texts, literary discourse analysis remains an under-researched aspect of the literature.

Literary discourse analysis, a branch of discourse analysis, is a novel approach in literary studies which demonstrates the interconnection between literature and (critical) discourse analysis (Dooga, 2009; Maingueneau, 2010).Literary works are most often encoded in esoteric parlances that require not just the intervention of literary critics to unravel but also (critical)discourse analysts (Odebode \& Odesanya, 2015). (Critical) Discourse Analysis views language as a social behaviour, and therefore, explores the use of language in the conveyance of social and political power (Amin, 2013). The application of discourse analytical concepts to literary texts, therefore, considers the "reciprocal envelopment of text and context, which implies shifting the core of the analysis: from the creator and his or her work to the conditions that make literary discourse possible" (Maingueneau, 2010, p. 1).

Literary discourse analysts tackle literature on two fronts: traditional literature studies and discourse analysis (Maingueneau, 2010, p. 2). This implies that literary discourse analysis relates literary texts (considered in themselves) to their contexts (the outside world of the text; "the setting of the text independently of discourse activity") (Maingueneau, 2010, p. 5). That explains the centrality of genre in literary discourse analysis since literature, itself, can be considered as "a network of genres, a certain configuration of legitimate speech activities" (Maingueneau, 2010, p. 6). Genre gives literary texts meaning because it embodies "the social reality in which the activities of all social participants are implicated" (Bawarshi, 2000, pp. 346-347 cited by Miall, 2002, p. 325). Halliday (1978) cited by Miall, (2002, p. 325) refers to it as "the register apparent in any given text-that is, the semantic and syntactic features that create the communicative situation, including the stance of the participants". Genre in literary discourse analysis denotes "communication frames", the "sets of norms associated with a certain category of speech situations" (Maingueneau, 2010, p. 6). The genre network of literature is not limited to literary genres ("the genres of literary works"), but includes literary genres that cut across other aspects of human existence and consequently integrates literary studies into larger spaces (Maingueneau, 2010, p. 7). It is, therefore, imperative to structure together the whole network of literary genres to comprehend the functioning of literary texts.

In spite of the novelty of literary (critical) discourse analysis, some scholars have beamed their research light on this interconnection by exploring language use and implications in literary works. Anderson (2018) adopts Fairclough's theory to perform a critical discourse analysis of Ola Rotimi's Our Husband Has Gone Mad Again with the aim of exposing the socio cultural and political issues in the text and their contextual imports. Yusuf (2016) likewise performs a critical discourse analysis of Wole Soyinka's The Beatification of Area Boy using Norman Fairclough's theory. This was done with a view to investigating the reflection of power dominance, imbalances, injustice and inequality via use of language among different strata in the society. In translation studies, Aidinlou, Dehghan \& Khorsand (2014) examine the translation quality in novel discourse by exploring the extent to which ideology and power relations play major roles in the two Persian translations of the political literary text, Orwell's Animal Farm, from the viewpoint of critical discourse analysis (CDA). None of the extant studies on literary (critical) discourse analysis has explored language use from the feminist perspective.

The present study, therefore, seeks to expand the literature by performing a critical discourse analysis of Tess Onwueme's The Broken Calabash and The Reign of Wazobia from the feminist perspective. The study, specifically, aims at performing a comparative feminist critical discourse analysis of the two plays by exploring the dramatic creation of female transgressors in the plays; the discourse structures in their dramatic creation; the ideological constructions of the discourse structures; and their implications in the furtherance or elimination of the instituted oppressive gender order. The next section presents an explanation on the analytical framework. 


\section{Feminist Critical Discourse Analysis}

Feminist Critical Discourse Analysis (FCDA), a praxis-oriented research angle at the nexus of Critical Discourse Analysis (CDA) and feminist scholarship, advances "rich and nuanced analyses of the complex workings of power and ideology in discourse in sustaining hierarchically gendered social orders" (Lazar, 2007, p. 141).Since, CDA critiques how power and dominance are (re) produced in social practices via the discourse structures of everyday interactions (Holmes, 2005), there arises, within the purview of CDA, the need to change substantively the existing gender order and relations which oppress and disempower women(Lazar, 2005; Alparslan, 2015). The need has, consequently, birthed a "feminist politics of articulation" influenced by feminist principles, in theorising and analysing the oppressive, yet innocuous stereotypical gender relations present in many social practices and variable across cultures (Wetherell, 1995, p. 141 cited by Lazar, 2007, p. 143).

FCDA critiques the workings of instituted "gender ideology and asymmetrical gender relations" in discourse structures in diverse social practices (Lazar 2007, p. 141). It demonstrates how hegemonic power relations are, explicitly and/or implicitly, "discursively produced, sustained, negotiated, and challenged in different contexts and communities" with a view to effecting social change (Lazar, 2007, p. 142). Thus, the impetus for FCDA lies in its social emancipatory and transformative goals. The imbrication of hegemonic gender power/relations and ideology in many social practices is often done subtly that it appears occluded, legitimate, natural, and therefore, innocuous to participants involved. Thus, the marriage of feminism with CDA helps in demystifying overtly expressed and implicit "gendered discourse practices" as well as "the interrelationships of gender, power, and ideology in discourse" (Lazar, 2007, pp. 145-146). FCDA focuses on social practices that are not only discursive in nature, but also "discursively represented in particular ideological ways" (Chouliariaki \& Fairclough, 1999 cited by Lazar, 2007, p. 149). This is because feminist critical discourse analysts see the stereotypical gender construction as an ideological structure based on physiological sex dichotomy characterised by a hierarchical relation of dominance. Thus, the interest of FCDA "lies in how gender ideology and gendered relations of power get (re)produced, negotiated, and contested in representations of social practices, in social relationships between people, people's social and personal identities in texts and talk" which is known as "gender relationality" (Lazar, 2007, p. 150). The goal of FCDA is the critiquing of ideological discourses which (re)produce and sustain a patriarchal social order - "relations of power that systematically privilege men as a social group, and disadvantage, exclude, and disempower women as a social group" (Lazar, 2007, p. 145).

In view of the above, FDCA entails "feminist analytical activism" in that it analyses the ways gender relations, power and dominance are discursively (re)produced and/or (counter-) resisted via "textual representations of gendered social practices, and through interactional strategies of talk" (Lazar, 2007, p. 149). The interrelationship of gender with various socio cultural systems of power that cut across social class, race/ethnicity, educational level, age, sexual orientation and geography demonstrate that gendered oppression is materially and discursively variable across cultures (Lazar, 2007). This acknowledges differences among women as well as differential types of gender oppression to which they are routinely subjected to (Lazar, 2007, p. 149). FCDA, therefore, needs to be "inflected by the specificity of cultural, historical, and institutional frameworks, and contextualised in terms of women's complexly constructed social identities" (Lazar, 2005, p. 149). Feminist CDA, then, is "implicitly comparative rather than universalising", and focuses more on "the discursive aspects of the forms of oppression and interests which divide as well as unite groups of women" (Lazar, 2007, p. 149).

Due to the overtly feministic, political, comparative, and most importantly, emancipatory and transformational agenda of FCDA, it provides a suitable and an enriching analytical framework for analysing literary discourse. The analytical principles of FCDA are, therefore, adopted as guiding framework in performing a comparative exploration of Tess Onwueme's The Broken Calabash and The Reign of Wazobia with a view to deconstructing explicitly expressed meanings of discourse structures coupled with occluded and nuanced meanings in the texts. This study seeks to analyse discourse structures characterised by "subtle and complex renderings of ideological assumptions and power relations" in the gendered social practices portrayed in the two plays (Lazar, 2007, p. 151), and their implications in the furtherance or elimination of gendered oppression. 
The study is expected to contribute to (critical) literary and discourse studies a perspective informed by feminist scholarship and also demonstrate the utilitarian role of language and discourse studies in the investigation of feminist issues in gender-based literary texts.

\section{Methodology}

Discourse situations that depict the dramatic creation of female transgressors in Tess Onwueme's The Broken Calabash and The Reign of Wazobia are extracted from the plays and subjected to qualitative analysis using relevant principles from Lazar's (2007) feminist critical discourse analysis.

\section{Data ANALYSiS}

The data analysis focuses on three FCDA principles, which are: gender relationality, prevailing ideological structures in the two plays and critical reflexivity. These principles will facilitate a critical analysis of the discourse structures that depict the transgressions of some female characters from the expected gender orders, the ideological structures projected by their transgressions, and the implications of their acts in the struggle against male dominance.

\section{GENDER RELATIONALity as IdeOlogical STRUCtURE}

Gender relationality focuses on discursive constructions of the behavioural expectations from men and women in diverse communities of practice (Lazar, 2007). It does not focus on a single gender; it rather examines the textual representations of the gender relations that exist between men and women in social practices in specific communities. This analytical focus is germane in that to understand better female transgressors in the plays, instituted mainstream gender relations in the societal settings of the two plays must first be comparatively analysed in order to enhance the understanding on how such gender relations participate differentially within hierarchies of oppression that subjugate women.

Gender relationality in the two plays differs, to a great extent, due to their differential socio-cultural foci. The Reign of Wazobia brings to the fore kingship succession issues while The Broken Calabash satirises the wanton celebration of male progeny, both plays situated within the African context. In The Reign of Wazobia, instituted gender relation recognises only males as kings; however, upon the demise of a male monarch, a maiden is elected by the priest and coronated as a "female Kingsurrogate" or "female regent" for three seasons until a new male king is crowned. Based upon this gender order in the play, Wazobia becomes the female regent but she wilfully refuses to relinquish power to a male successor after the expiration of three seasons.

The same deviant attitudinal posture is dramatised in the female protagonist, Ona, in The Broken Calabash. The gender relation in her Ogwashi-Uku tradition stipulates that a maiden, who is the only child of her parents, is not expected to be married out, but "must bear children into her immediate family to propagate the lineage" (p.66). Such a maiden is, however, given the option of marrying another female into the family to assume her role. The traditional name for such a maiden is "idegbe". The gender relation in the socio-cultural domain of the play stamps the supremacy of male off springs to female, and therefore, institutionalises the idegbe tradition of male progeny in the family at the expense of female off springs. However, Ona, an idegbe, refuses to comply with the dictates of her society. The play dramatises her incessant struggles against the oppressive culture.

Wazobia and Ona, in the two plays, represent female transgressors whose actions reveal the possibility of a dialectical contest between the structural permanence of the prevailing gender relations that disempower women and the advertent struggles/transgressions of women engaged in the practical social practices. The observed gender relationality in the two plays portrays a dualism in the gender structure; a dualism that tilts favourably towards men at the expense of women's freedom. It also demonstrates that although the instituted gender relational structures are hegemonic, they are contestable and can be ruptured.

On another level however, gender relationality examines the dynamic forms of maleness and femaleness. This study will only focus on the dynamic forms of femaleness. Analysing relations among the groups of women created in the two plays is crucial in that such analysis portrays how women "rally together in solidarity to oppose some form of discrimination, or how women operating within androcentric cultures ... help perpetuates exist attitudes and practices against other women" (Lazar, 2007, p. 150). 
In the two plays, women gender relationality differs. The Reign of Wazobia depicts a huge solidarity demeanour among the women of Anioma Kingdom towards Wazobia, their female King surrogate, as seen in the discourse structure extract below:

Text 1: WAZOBIA, confused and frightened, looks for any friendly face but she is alone. Suddenly, the cock crows. Women from behind the throne sound their war-cries... they advance, naked and in unison, forman arc behind WAZOBIA... (p. 61)

The arc formed by the women around Wazobia when men seek to oust her from the throne is a metaphor for support and solidarity. Although the arc symbolises massive women support, a few women like Anehe and $\mathrm{Wa}$, operate within the culture to perpetuate male dominance against women as seen in Text 2:

Text 2: WA: It beats me too that the gods should by-pass all the princesses in this royal hose and choose a mere girl from such a poor home to rule us... (p.12)

It could be assumed from the discourse extract above that Anehe and Wa's dissidence could be linked to envy. However, in the play, the number of women supporters far outnumbers women dissidents, thereby resulting in huge success for the king.

This is, however, not the case in The Broken Calabash where Ona is presented fighting a lone battle against the familial idegbe tradition. The few female characters in the play, asides Ona, fail to give the protagonist the needed support; they are rather portrayed as idegbe tradition-enforcers. Characters like Oliaku, Ona's mother, and Adagor, Ona's paternal aunt, all act to reinforce and perpetuate the tradition as seen in the outburst of Adagor when Otu Agada, Diaku's father come for engagement proposal between Ona and Diaku:

Text 3: ADAGOR: ... No wonder they say you are a family of fools...

Don't you know that Ona is an idegbe and that she cannot marry outside this family...? (p. 102)

Her rhetorical question above has a reinforcement rhetorical effect. The question not only foregrounds the unchanging and sacred nature of the idegbe tradition, it also serves as a cautionary note meant to ward off Diaku, his father and kinsmen from Ona The repulsiveness of Adagor towards Ona's engagement proposal presents Ona as a sacrificial lamb whose freedom is at stake to sustain male progeny; she becomes an accursed maiden in a cultural bondage as seen in the foregrounded Nominal Group, MY MISERY, in Text 4:

Text 4: ONA: And that's my undoing, MY MISERY!... Just to go out like you now, I can't without a barrage of questions: where are you going, Ona? Whom are you going to? Why must you go now?... I stay put in the house... (pp. 74-76)

The only female friend she has who should solid arise with her lacks the empathy and she eventually betrays Ona by marrying Diaku, Ona's finance. This act of betrayal furthers aggravates Ona and spurs her to self-revenge.

As analysed above, Wazobia and Ona are female transgressors who advertently deviate from gendered relational expectations. The hegemonic gender structures they rupture in the plays coupled with the dynamic relations among co-women in giving support to the transgressors or otherwise have been comparatively portrayed in this section. This is with a view to presenting a background knowledge of the instituted gender relations between men and women in the plays and the deviant stances of the female transgressors as well as the supports (or otherwise) from co-women in the struggles of the two protagonists.

\subsection{Comparative Study of Prevailing Ideological Structures in the Two Plays}

The gender relationality analytical backgrounds in the previous section facilitate the elicitation of prevailing ideological notions in the plays. Four ideological structures can be constructed from the discourse structures in the plays, which are: biased dualism of the traditional gender relations; female 
transgression as a counter-move against mainstream gender relations; and the formidability of women's solidarity. Each of these will be examined in turn:

\subsection{Biased Dualism of the Traditional Gender Relations}

A comparative study of the two plays reveals that they both operate androcentric cultures. Although these cultures are inflected by variable social practices, nevertheless, the plays depict the superiority of men while relegating women to the constitutive other in a disempowered state. The Reign of Wazobia mirrors a society that recognises only male monarchs, elected females who function as Kingsurrogate after the demise of any king have no authority and the tenure of the post expires after three seasons as seen in Text 5:

\section{Text 5: WAZOBIA: ... Ask yourselves}

Why the law prescribes a female Regent

Where are the men

If rulership is the sole preserve of men?

Do you think they contradict themselves when

They make a female regent rule for only

Three seasons when a king passes beyond

They plant us as king unasked

And supplant us at will... (p. 7)

In the discourse extract above, Wazobia exposes the prejudiced nature of the coronation of female regent via a series of rhetorical questions. Her probings seek to question the rationale behind female King-surrogacy in a society that values only male supremacy. Her passionate speech implicitly reveals that the system of female King-surrogacy is a mockery of women empowerment. She validates her views further in the text via the revelatory declaration (they plant us as king unasked, and supplant us at will) that mirrors the disempowerment of women in that female regents have no say in their coronation and removal as kings. This view is further entrenched when the Priestof Anioma kingdom, and Iyase, a prominent chief, made remarks in different discourse situations about the instituted non-participatory role of women in the state politics, in Texts 6 and 7:

Text 6: PRIEST OF ANI: Since when have women become the pillar of the state?... (p. 10)

Text 7: IYASE: ... if we must deliberate on such serious state matters, women ... must be sent away... (p. 27)

While talking to the women leader, Omu, the Priest deploys a rhetorical question to reinforce the value that women have no say in the affairs of the state. Though Omu is recognised as the leader of all women, her role is merely ceremonial just like the role of King-surrogates.

A similar trend is observed in The Broken Calabash, though in a different social practice. Ona, an Idegbe must sacrifice her freedom to sustain the tradition of male progeny as highlighted in Text 8:

Text 8: COUTUMA: ... Ona, cannot marry outside this family. You are an Idegbe! (p. 108)

The negation not attached to the modal of possibility as well as the final exclamatory remark in Text 8 reinforces the sacredness of the tradition. The Idegbe tradition is, therefore, a celebration of patrilineality, just like male monarchy in The Reign of Wazobia. Patrilineal succession gives priority to males only; it is, consequently, biased to women.

The two plays, therefore, reveal subtly the discriminative and suppressive inclinations of the gender relations between men and women in the Nigerian contextual domains. This demonstrates that the gendered relation ideology in the socio cultural contexts of the plays is dualistically biased, hegemonic, and to some extent, consensual since the ideology has been enacted and circulated as natural, commonsensical and normal. The assumed normalcy, thus, obscures its oppressive and dominating inclinations. 


\subsection{Female Transgression as Advertent Counter-Move}

Wazobia and Ona advertently deviate from gendered behavioural expectations, and are labelled as transgressors. Their transgressions represent their counter stances to the routinely practiced social practices in their domains, and this shows that the natural order is contestable and friable. The friability of the prevailing gendered order violates its sacredness and naturalness. Wazobia, the female King-surrogate, refuses to step down from the throne after the expiration of three seasons as revealed in her discourse structure below:

\section{Text 9: WAZOBIA: ... Men accept}

But no! They have come again!!

They want Wazobia ousted...

...Wazobia too resists and will persist ...

... I, Wazobia have tasted power and WILL

NOT GO. (p. 6)

Wazobia's resistance against her removal via the underlined assertions in Text 9is a discursive counter averment meant to prove that the election and removal of female regents is not the prerogative of men. Likewise, Onaoverly rejects her Idegbe role as seen in her outburst below:

Text 10: ONA: ...You people have a very ambitious murder-plan. You will not only slaughter me on the altar of your decadent tradition, but would also want another female head. I say-to Hell with your Tradition. Homestead! Norm! All!

Let the wind blow-Let the shaky homestead be blown. Anything which cannot stand the force of change must be uprooted or be blown into oblivion by the storm heralding the new season! (p.109)

The protagonists, Ona and Wazobia, are depicted as activists involved in the struggles for contestation and change. Their transgression serves as a nexus between the two plays and it construes the belief that the seeming natural and innocuous gendered order is friability, and thus, must be overthrown for a social change of emancipation for women. Female transgression thus presents a dialectical tension between the natural structural permanence of the oppressive gendered relations and the practical activities of the populace engaged in the social practices (Chouliaraki \& Fairclough, 1999 cited by Lazar, 2007). It also demonstrates the possibility that the natural gendered ideology can be ruptured to effect a social change.

Although the oppositional impacts of female transgression are appreciable in the plays, each play must, however, be assessed in relation to co-women's material and psychological supports.

\subsection{The Formidability of Women's Solidarity}

Women's solidarity becomes a unifying force that defines Wazobia's success as a female transgressor. In the discourse structures 11 and 12 below:

Text 11: OMU: This is why you must stand behind Wazobia with your bosom, your king,that men will not penetrate. At this very moment, men hold their meeting to unseat Wazobia.

Wazobia is "us".

We are Wazobia.

Together we stand. What they plan is abominable and we shall match force with force.

Together, we join hands... (p. 52)

Text 12: OMU: Our great king 


\begin{abstract}
We, your people have come together, to form this arc around you . That you may continue to reign for our own glory. That the world may see. We form this arc. To shield us from the stampede of masquerades (p. 53)
\end{abstract}

The declarative twin assertions: "Wazobia is us; "We are Wazobia", do not just signify the bond of unity among the women, but also their common goal of resistance against a common enemy, male hegemony. When men rush to the palace-square in arms to force Wazobia into exile, she initially appears "confused and frightened" (p. 61), but the women in unison appear from behind the throne to form an arc around her. She then regains her deviant and bold composure. The arc, a metaphorical indication of women's solidarity for Wazobia's reign as king, forces men into retreat and submission, and gains victory for Wazobia.

Unlike Wazobia, Ona, in The Broken Calabash, is left to fight a lone battle against the Idegbe tradition. The few women characters in the play exert no conscious effort to stand by her to overthrow the tradition; they are rather portrayed as women-complicit trying to coerce Ona into submitting to the dictates of her father as seen in Texts 13:

Text 13: OLIAKU: You refuse to hear your father? Obida forbids!...

They have cast a spell on my only child, Ona? (p. 108)

Oliaku, Ona's mother, lends no support to her daughter as seen in the rhetorical questions she poses to Ona, probing her deviant attitude to the Idegbe tradition. With no material and psychology support from co-women, Ona is pictured as a lone struggler and this leads eventually to her defeat at the end as portrayed in Text 14:

Text 14: ... (Ona hears this and screams, fainting and falling) (p. 116).

Ona's fall in Text 14 signifies her defeat. It is a metaphorical depiction of the consequence of her lone transgression. It can, therefore, be presumed that if Ona had received the women's support like Wazobia in The Reign of Wazobia, she would have become undefeatable like Wazoba, the king.

\title{
6.5. Critical Reflexivity
}

Wazobia and Ona's stances in the plays show how men's power and dominance can be discursively resisted in a dynamic struggle over challenging the natural gender order and effecting a social transformation of structures of gender oppression. The two plays reveal the institutionalisation of consensual androcentrism in many institutional cultures and discourse, in which both men and women are complicit through their habitual participatory roles in the perpetuation of such oppressive cultures in their particular communities of practice (Lazar, 2007).

Significantly, the impact of the deviance of the female transgressors is worth considering. In The Reign of Wazobia, going against gendered order resulted in overthrowing the existing gender relation. Only the women could be seen at the end of the play surrounding the throne while the men retreat. However in The Broken Calabash, Ona, the female transgressor is defeated by the tradition she fails to bow to. At the end of the play as seen in Text 14, she forcefully bows to the tradition she has erstwhile rejected. It can, therefore, be presumed that Ona's transgression does not result in the eradication of the existing gender structure, but in the subjugation of the female transgressor herself. Ona's plight buttresses Lazar's (2007, p. 148) view that "deviations from gender-appropriatenorms are policed and contained in the presence of a prevailing discourse of heteronormativity". The two plays, therefore, call for critical reflexivity of women inclusivity in the struggle against male oppression.

According to Giddens (1991) cited by Lazar (2007, p. 152), critical reflexivity is the means by which "there is an increased tendency for people in this period to utilize knowledge about social processes and practices in a way that shapes their own subsequent practices". A comparative study of the two plays demonstrates the significance of a bond of unity among womenfolk in fighting male oppression. This study mirrors the view that female transgressors can only succeed in going against expected gender order if they get the material and psychological supports of co-women; otherwise, their deviance will only amount to self-destruction which will, consequently, reinforce the futility of fighting against existing gender structures. 
Aside institutional critical reflexivity, female transgressors or feminists need to engage in critical selfreflexivity lest their practices end up in perpetuating rather than eliminating male oppression. Ona in The Broken Calabash is a typical example of a character whose deviant stance fails to suppress the existing order because she is a lone fighter. She becomes vengeful which leads to her destruction. Her struggle fails to achieve the expected result. Her chosen retaliatory weapon is flawed, and the resultant unpleasant result, therefore upholds inadvertently the sacredness of the Idegbe tradition.

\section{CONCLUDING REMARKS}

The present study has demonstrated the significant role of women's solidarity in the fight against male oppression via a comparative feminist critical discourse analysis of Tess Owueneme's The Reign of Wazobia and The Broken Calabash. By examining gender relationality as instituted ideology in the two plays and the ways the two protagonists have deviated from the prevailing gender orders, Wazobia and Ona are portrayed as female transgressors who seek tenaciously to overthrow male hegemony. Their transgressions are depicted as counter-ideological move meant to portray the friability of the existing order. The success and failure of Wazobia and Ona, respectively, foreground the relative importance of women's solidarity in fighting a common enemy, male oppression.

\section{REFERENCES}

Acheoah, J. E. \&Sunday, J. A. (2014). Communicative strategies in contemporary Nigerian drama: A stylistic analysis of Ahmed Yerima's The Lottery Ticket. Scholars Journal of Arts, Humanities and Social Sciences, Sch. J. Arts Humanit. Soc. Sci., 2(1), 32-36.

Adegoju, A. (2016). Our land, our struggle, our dream: A poststructuralist reading of Niger Delta conflict rhetoric in Ahmed Yerima's Hard Ground, African Identities, 15 (3), 231-246.

Adeniji, A. \& Osunbade, N. (2014a). Pragmatic acts in characters' utterances in Ahmed Yerima's Mojagbe. Research on Humanities and Social Sciences, 4 (8), 11-20.

Adeniji, A. \& Osunbade, N. (2014b). Pragmatic functions of tradition-motivated discourses in Ahmed Yerima's Ajagumale. International Journal of English and Linguistics Research 2 (2), 1-14.

Aidinlou, N.A., Dehghan, H. N., \& Khorsand, M. (2014). Ideology, change \& power in literature and society: A critical discourse analysis of literary translations. International Journal of Applied Linguistics \& English Literature, 3(6), 25-41.

Alparslan N. (2015). Women chewing gum: Feminist critical analysis of advertising as symbolic violence. ilef dergisi 2(2), 35-54.

Amin, D. (2013). The Application of Critical Discourse Analysis in Literary Criticism: Challenges and Solutions. CMC Proceedings76. Retrieved from https://www.researchgate.net/publication/3184929 51_The_Application_of_Critical_Discourse_Analysis_in_Literary_Criticism_Challenges_and_Solutions [accessed May 15 2018].

Anderson, U. (2018). Critical discourse analysis of Ola Rotimi’s Our Husband has Gone Mad Again. Retrieved from https://afribary.com/works/critical-disourse-analysis-of-ola-rotimi-rdquo-s-our-husband-has-gonemad-again-7622

Asiyanbola, A. A. (2016). A pragma-linguistic analysis of J.P. Clark's 'The Casualties' and Kofi Awoonor's 'Song of Sorrow'. ISEL 12 (1), 1-15.

Awoyemi, T. (2014). The playwright as seer: Girl-child marriage in Aetu by Ahmed Yerima. International Journal on Studies in English Language and Literature (IJSELL), 2 (9), 6-11.

Bawarshi, A. (2000). The genre function. College English, 62, 335-360.

Cheru, M. Z. (2013). Old and new ways to celebrate a bride. In A. Kanengoni (Ed.), BUWA: A Journal on African Women's Experiences, 2(2), 81-85.

Chouliaraki, L., \& Fairclough, N. (1999). Discourse in late modernity: Rethinking criticaldiscourse analysis. Edinburgh, UK: Edinburgh University Press.

Dahlerup, D. (1987). Confusing concepts - confusing reality: A theoretical discussion of the patriarchal state. In A. S. Sassoon (Ed.) Women and the State. London: Hutchinson.

Dooga, J. T. (2009). Linguistic choices and gender roles in new Nigerian Literature: An examination of Alpha Emeka's The Carnival and Razinat Mohammed's A Love like a Woman's and Other Stories. African Research Review International Multi-Disciplinary Journal, Ethiopia 3 (3), 133-146.

Evwierhoma, M. I. E. (2016). Mother is gold: The mater the matter and women-centred approaches in Nigerian drama and theatre. An inaugural lecture presented on Thursday, 21 January, 2016. Retrieved from http://oer.uniabuja.edu.ng/wp-content/uploads/2017/12/\%E2\%80\%9CMOTHER-IS-GOLD-THEMATER-THE-MATTER-AND-WOMEN-CENTRED-APPROACHES-IN-NIGERIAN-DRAMA... 
Ezenwa-Ohaeto, N. (2015). Fighting patriarchy in Nigerian cultures through children's literature. Studies in Literature and Language, 10 (6), 59-66.

Ezenwanebe, O.C. (2008). The empowered women in Ahmed Yerima's Drama. The Creative Artist: A Journal of Theatre and Media Studies 2(1), 185-204.

Giddens, A. (1991). Modernity and self-identity. Cambridge, UK: Polity Press.

Halliday, M. A. K. (1978). Language as social semiotic: The social interpretation of language and meaning. London: Arnold.

Hasan, R. (1985). Language, context and text: Aspects of language in a social-semiotic perspective. Geelong, Vic.: Deakin University Press.

Holmes, J. (2005). Power and discourse at work: Is gender relevant? In M. M. Lazar(Ed.), Feminist critical discourse analysis: Gender, power and ideology in discourse (p.31-60). London: Palgrave.

Kies, D. (1992). The uses of passivity: Suppressing agency in Nineteen Eighty-four. InM. Davies \& L. Ravelli (Eds.), 229-250.

Kong, L.L.L. \& Chan, J. (2000). Patriarchy and pragmatism: Ideological contradictions in state policies. Asian Studies Review 24(4), 501-531.

Katongo, C. B. (2013). Elongation of the Labia Minora: A violation of women's bodily autonomy. In A. Kanengoni (Ed.), BUWA: A Journal on African Women's Experiences, 2(2), 30-33.

Lazar, M. M. (Ed.) (2005). Feminist critical discourse analysis: Gender, power and ideology in discourse. New York: Palgrave Macmillan Ltd.

Lazar, M. M. (2007). Feminist critical discourse analysis: Articulating afeminist discourse praxis. Critical Discourse Studies, 4 (2), 141-164.

Maingueneau, D. (2010). Literature and discourse analysis. Acta Linguistica Hafniensia, International Journal of Linguistics, Volume 42, Supplement 1, 147-157.

Makama, G. A. (2013). Patriarchy and gender inequality in Nigeria: The way forward. European Scientific Journal 9 (17), 115-144.

Miall, D. S. (2002). Literary Discourse. In A. Graesser, M. A. Gernsbacher, \& S. R. Goldman (Eds.).Handbook of Discourse Processes (pp. 321-355). Mahwah, NJ: Lawrence Erlbaum Associates.

Nolas-Alausa, T. (2012). The African woman and feminism: A study of two selected texts by Tess Onwueme. Retrieved from http://www.academia.edu/13539840/the_african_woman_and_feminism_a_study_of_two_selected_texts_ by_tess_onwueme

Nwanya, A. N., \& Ojemudia. C. C. (2014). Gender and creativity: The contributions of Nigerian female writers. Global Journal of Arts, Humanities and Social Sciences 2 (9), 50-62.

Odebunmi, A. (2006). A pragmatic reading of Ahmed Yerima's proverbs in Yemoja,Attahiru, and Dry leaves on Ukan trees. Intercultural pragmatics. 3(2), 153-169.

Odebode, I. \& Odesanya, A. (2015) Socio-pragmatic analysis of Ahmed Yerima's Ade Ire. International Journal of Language and Linguistics 2 (1), 108-118.

Ola, R. (1977). Our Husband has Gone Mad Again. London: Oxford University Press.

Onwueme, T. (1984). The Broken Calabash. Heinemann Educational books Plc, Ibadan.

Onwueme, T. (1988). Tell It To Women. Newark, New Jersey: African Heritage Press.

Onwueme, T. (1992). The Reign of Wazobia and Other Plays. Heinemann Educational books Plc, Ibadan

Orwell, G. (1951). Animal Farm. England: Penguin Books.

Orwell, G. (1982). Nineteen Eighty-Four. New York: Penguin Books.

Oyedepo, S. (2002). The Rebellion of the Bumpy-Chested. Ilorin: Delstar.

Rotimi.O. (1974). Ovonramwen Nogaisi : An Historical Tragedy in English.Ibadan: Ethiope Publishing Corporation, University Press PLC, Ibadan.

Sofola, Z. (1977). The Sweet Trap. Ibadan: Oxford University Press.

Soyinka, W. (1964). The Trials of Brother Jero. In The Jero Plays (pp. 7-45). Ibadan: Spectrum Bks. Ltd.

Soyinka, W. (1995). The Beatification of Area Boy: A Lagosian kaleidoscope. Ibadan: Spectrum.

Udengwu, N. (2002). Three female playwrights in Nigeria: The question of identity. In J. Z. Okwori, J. Z. (Ed.).Nigerian Theatre Journal, 7(1), 130-139.

Wetherell, M. (1995). Romantic discourse and feminist analysis: Interrogating investment, power and desire. In S. Wilkinson \& C. Kitzinger (Eds).Feminism and discourse: Psychological perspectives (pp. 128-44). London: Sage. 
A Comparative Study of Female Transgressors in Tess Onwueme's The Broken Calabash and the Reign of Wazobia: A Feminist Critical Discourse Analytical Perspective

Wilson, S. (2013). The State, culture and oppression. In A. Kanengoni (Ed.). BUWA: A Journal on African Women's Experiences, Vol. 2(2), 6-11.

Yerima, A. (2001). The Sisters. Ibadan: Kraft Books.

Yerima, A. (2004). The Portraits. The Angel and Other Plays (pp. 144-196). Ibadan: Kraft Books.

Yerima, A. (2004). The Mirror Cracks. The Angel and Other Plays (pp. 113-139). Ibadan: Kraft Book.

Yerima, A. (2007). Aetu. Ibadan: Kraft Books.

Yerima, A. (2008). Mojagbe. Ibadan: Kraft Books Limited.

Yusuf A. (2016). Critical Discourse Analysis of Wole Soyinka's The Beatification of the Area Boy, Munich, GRIN Verlag. Retrieved from https://www.grin.com/document/339945

\section{AUTHOR'S BIOGRAPHY}

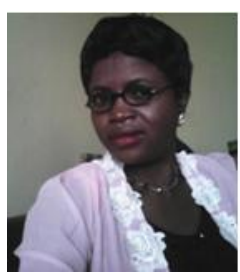

Adetutu Aragbuwais, a Lecturer in the Department of English and Literary Studies, Ekiti State University, Ado Ekiti. She holds a Ph.D in English Language from Obafemi Awolowo University, Ile-Ife. Her areas of specialization are Feminist Critical Discourse Analysis, Computer-Mediated Discourse Analysis, Critical Dialogism and Gender Studies.

Her Email address is oyearagbuwa@gmail.com.

Citation: ARAGBUWA, Adetutu. "A Comparative Study of Female Transgressors in Tess Onwueme's The Broken Calabash and the Reign of Wazobia: A Feminist Critical Discourse Analytical Perspective" International Journal on Studies in English Language and Literature (IJSELL), vol 6, no.8, August 2018, pp. 50-61. doi:http://dx.doi.org/10.20431/2347-3134.0608006.

Copyright: () 2018 Authors. This is an open-access article distributed under the terms of the Creative Commons Attribution License, which permits unrestricted use, distribution, and reproduction in any medium, provided the original author and source are credited. 